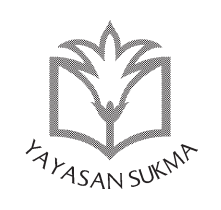

SUKMA: JURNAL PENDIDIKAN

ISSN: 2548-5105

Volume 1 Issue 1, Jan-Jun 2017, hlm. 197-218

\title{
INSTITUSIONALISASI MANAJEMEN KONFLIK BERBASIS SEKOLAH
}

\section{Rizal Panggabean}

Universitas Gadjah Mada Yogyakarta, Indonesia email: rizal.panggabean@yahoo.com

\begin{abstract}
Abstrak
Artikel ini membahas institusionalisasi atau pelembagaan manajemen konflik berbasis sekolah (MKBS). $M K B S$ adalah seperangkat pengetahuan dan keterampilan yang amat penting supaya sekolah menjadi lingkungan belajar yang aman bagi semua. Setelah menguraikan beberapa komponen utama MKBS, artikel ini membahas tiga dimensi pelembagaannya, yaitu peta jalan individu, fokus rujukan kelompok, dan konstitusi organisasi.
\end{abstract}

Kata Kunci: Manajemen konflik berbasis sekolah; kurikulum proses; mediasi sejawat; kelas yang damai; sekolah yang damai; institusionalisasi MKBS. 


\section{Pendahuluan}

Kekerasan di sekolah, yang sering disorot orang tua, siswa, dan masyarakat, sebenarnya sudah tak dapat lagi diterima atau dibenarkan. Sebab, saat ini sudah ada pengetahuan, baik teoretis maupun praktis, yang memungkinkan guru, siswa, dan sekolah menghadapi dan mengelola konflik supaya tidak mengarah kepada kekerasan. Pengetahuan teoretis tersebut terdiri dari gagasan, hasil pengamatan, temuan penelitian, dan proposisi yang dihasilkan berbagai disiplin ilmu seperti pendidikan, psikologi, perdamaian, dan resolusi konflik, khususnya yang menyangkut konflik dan kerjasama. Pengetahuan praktis tersebut terdiri dari seperangkat prosedur menangani atau mengelola konflik dan kekerasan, yang telah dicoba, dan terus dievaluasi dan dikembangkan, di sekolah.

Oleh sebab itu, yang perlu dipikirkan kalangan pendidik di negeri kita adalah bagaimana membawa pengetahuan tersebut ke sekolah. Hal ini sangat relevan mengingat sekolah di Indonesia mengalami berbagai bentuk kekerasan. Nilai dan praktik nirkekerasan masih jauh dari budaya sekolah kita. Perkelahian atau tawuran pelajar, baik yang berasal dari sekolah yang sama maupun dari sekolah yang berbeda, sering muncul di media. Kadang-kadang, perkelahian ini menelan korban jiwa. Selain itu, perundungan atau bullying, serangan seksual, prasangka buruk terhadap kelompok yang memiliki latar belakang ekonomi, suku, dan agama yang berbeda, adalah masalah-masalah dalam kehidupan siswa. Bahkan, tak jarang terdengar radikalisme dan ekstremisme keagamaan sudah masuk ke sekolah. Belajar, sebagai fokus utama siswa dan sekolah, sering terganggu karena masalah-masalah ini.

Pengetahuan tentang pencegahan kekerasan dan pembinaan prilaku positif di kalangan siswa telah berkembang dan siap diterapkan di sekolah, dengan pendekatan tepat dan persiapan memadai. Pendekatan yang tepat itu tidak memerlukan polisi, satuan pengamanan sekolah, atau sistem pemantau elektronik. Persiapan yang memadai itu memerlukan pengambilan 
$\overline{\text { keputusan yang berwenang dan peran serta seluruh pemangku }}$ kepentingan di sekolah. Tulisan ini mendiskusikan beberapa jalur yang dapat digunakan membawa pengetahuan teoretis dan praktis tersebut ke sekolah. Istilah yang digunakan menggambarkan pengetahuan teoretis dan praktis tersebut adalah "manajemen konflik berbasis sekolah", disingkat MKBS. Selanjutnya, istilah "institusionalisasi" dan "pelembagaan", yang dijelaskan lebih lanjut di bawah, merujuk kepada seperangkat aturan yang menata interaksi bersama di sekolah.

Dengan demikian, bagian pertama tulisan ini akan membahas beberapa unsur MKBS yang dapat dilembagakan ke dalam proses belajar mengajar di sekolah. Kemudian, tulisan ini membahas beberapa strategi pelembagaan yang dapat digunakan. Akhirnya, bagian penutup menampilkan beberapa catatan mengenai institusionalisasi MKBS.

\section{Manajemen Konflik Berbasis Sekolah}

Ada banyak pendekatan yang dapat digolongkan ke dalam MKBS. Crawford dan Bodine (1996) menyebut empat. Keempatnya adalah kurikulum proses, mediasi, kelas yang damai, dan sekolah yang damai. Dua pendekatan dapat ditambahkan di sini, yaitu antiperundungan (anti-bullying) dan peran keluarga dan masyarakat dalam MKBS (Panggabean dkk, 2015). Keenam unsur MKBS yang diterakan di atas akan diuraikan secara ringkas di bawah ini.

\section{Kurikulum Proses}

Sekolah dapat menyediakan waktu-waktu khusus yang digunakan untuk mengajarkan pengetahuan dan keterampilan resolusi konflik kepada guru dan siswa. Crawford dan Bodine menamakan ini pendekatan "kurikulum proses", yang mengintegrasikan pengetahuan dan keterampilan resolusi konflik ke dalam kehidupan guru dan siswa selama di sekolah. Dalam hal ini, pengetahuan dan keterampilan itu tidak dijadikan sebagai materi yang harus dipelajari, dihapal, dan dilatih, yang disebut dengan 
"kurikulum produk" atau "kurikulum hasil" (Knight, 2001). Akan tetapi, pengetahuan dan keterampilan tersebut menjadi ciri dan bagian dari interaksi serta pengalaman sehari-hari di sekolah. Pengetahuan dan keterampilan resolusi konflik menjadi bagian dari keterampilan hidup dan sosial siswa.

Sekolah memiliki banyak pilihan waktu khusus mempelajari manajemen dan resolusi konflik. Misalnya, ada sekolah yang mengajarkan resolusi konflik sepanjang satu semester dalam pelajaran yang tersendiri. Sekolah lain mengadakan pelatihan resolusi konflik dengan durasi yang bervariasi - satu sesi atau beberapa sesi dalam satu semester. Sekolah juga bisa mengadakan program pelatihan resolusi konflik untuk guru, siswa, dan staf sekolah yang diadakan secara berkelanjutan. Sekolah yang lain lagi mengintegrasikan keterampilan dan pengetahuan resolusi konflik ke dalam mata pelajaran yang ada, melalui simulasi, bermain peran, diskusi, dan kegiatan belajar bersama (Crawford dan Bodine 1996, 15).

Jenis keterampilan dan kemampuan resolusi konflik yang dipelajari dalam waktu-waktu yang disediakan juga bervariasi. Kepentingan dan kebutuhan khusus sekolah akan menjadi pertimbangan utama ketika memilih keterampilan dan kemampuan yang dipelajari. Pemecahan masalah, negosiasi, komunikasi nirkekerasan, dan pencegahan kekerasan adalah beberapa jenis kegiatan yang populer. Mediasi dan tahap-tahapnya adalah kegiatan lain dalam kurikulum proses di bidang resolusi konflik.

\section{Program Mediasi}

Sekolah melatih sejumlah siswa mengenai prinsip dan kemampuan dasar mediasi, dengan meminta bantuan dari mediator yang sudah terlatih. Para ahli pendidikan melihat mediasi dapat dimanfaatkan sebagai pendekatan alternatif terhadap praktik tradisional seperti skorsing dan hukuman fisik. Salah satu program mediasi yang perlu mendapatkan perhatian khusus adalah mediasi sejawat atau peer mediation. Mediasi adalah perundingan dengan bantuan pihak ketiga. Dalam hal ini, dua siswa 
yang sedang dihadapkan kepada masalah atau konflik mengikuti sesi mediasi yang dipimpin pihak ketiga yang disebut mediator. Mediator membantu mereka menyelesaikan konflik tersebut. Mediasi ini disebut "mediasi sejawat" karena baik pihak yang berkonflik maupun mediatornya adalah siswa.

Proses mediasi sejawat terstruktur sehingga memungkinkan dua siswa sebagai pelaku konflik membicarakan dan menyelesaikan persoalan dengan bantuan siswa lainnya sebagai penengah. Produk akhir yang dihasilkan adalah kesepakatan damai tertulis, yang dituangkan dalam formulir yang telah disediakan. Siswa dengan latar belakang bermacam-macam (gender, agama, etnis, status sosial, prestasi akademik, minat) dipilih dan dilatih menjadi calon mediator. Kelab mediasi bisa dibentuk dan dikelola guru yang juga telah mengikuti pelatihan mediasi. Guru tersebut bertindak sebagai koordinator yang menyiapkan sesi mediasi antara siswa penengah dengan siswa pelaku konflik. Guru juga memberikan pelatihan mediasi kepada para mediator siswa.

Sesi mediasi dapat dilakukan karena beberapa alasan: Berdasarkan permintaan siswa yang terlibat konflik, berdasarkan permintaan guru, atau berdasarkan ketentuan yang sudah diatur di dalam statuta atau kebijakan sekolah. Guru atau koordinator mediasi menentukan perselisihan atau konflik apa saja yang ditangani dengan mediasi. Prosesnya bisa dijalankan sebelum atau setelah sekolah usai, jam istirahat siang, atau selama jam pelajaran atas ijin guru. Jika kesepakatan yang sudah dibuat gagal diterapkan, pihak-pihak yang berkonflik dapat menggunakan mediasi lagi. Atau, jika diperlukan, sekolah, melalui konselor dan kepala atau wakil kepala sekolah, dapat secara langsung mengintervensi konflik antar-siswa tersebut (Crawford dan Bodine 1996, 23-24; Panggabean dkk. 2015, 73-89).

\section{Kelas yang Damai}

Kelas yang damai, atau peaceable classroom, adalah komponen lain MKBS. Dilihat dari teori dan praktik pendidikan, 
kelas yang damai berakar pada beberapa tradisi. Yang terpenting di antaranya adalah bekerja sama dalam proses belajar mengajar atau collaborative learning (Slavin 1980; Slavin 2014), dan manajemen kelas nirpaksa atau non-coercive classroom management. Noel (2008) menyebut belajar kolaboratif dan manajemen kelas nirpaksa sebagai dua pilar pendidikan resolusi konflik. Kelas yang damai, dengan demikian, menghindari beberapa ciri proses belajar mengajar yang bersifat negatif, yaitu suasana yang otokratis, serba menghukum, menggunakan kekerasan fisik, dan menekankan kontrol eksternal. Sebaliknya, kelas yang damai mengutamakan komunikasi dan interaksi nirkekerasan dan pembinaan kemampuan dasar di bidang pemecahan masalah.

Guru yang menerapkan resolusi konflik dalam mata pelajarannya dapat menciptakan suasana kelas yang mendukung resolusi konflik dan perilaku pro-sosial. William Kreidler, pelopor peaceable classroom, berpendapat bahwa kelas adalah sebuah komunitas yang saling peduli dan menghargai. Ciri-cirinya adalah kerjasama, komunikasi, ekspresi emosional, apreasiasi terhadap perbedaan, dan resolusi konflik (Crawford dan Bodine 1996, 33). Beberapa penelitian yang dilakukan Johnson dan Johnson (1995; 2008) menunjukkan arti penting kelas yang damai dalam meningkatkan hubungan sosial yang positif, kerjasama antarsiswa dalam kelompok-kelompok kecil yang menyelesaikan tugas sekolah, dan penerapan kontroversi akademik dalam mengatasi konflik intelektual.

Dengan menggunakan strategi belajar kolaboratif dan manajemen kelas nirpaksa, guru bisa mengintegrasikan pendidikan resolusi konflik ke dalam mata pelajaran yang ada. Ketika mengikuti pelajaran sejarah, siswa dapat mendiskusikan keberhasilan dan kegagalan negosiasi yang dilakukan pemerintah Indonesia dan Belanda pada masa perang kemerdekaan. Mereka juga dapat mengkaji tokoh seperti Mahatma Gandhi, Abdul Gaffar Khan, Nelson Mandela, Abdurrahman Wahid, dan sumbangan mereka bagi perdamaian. Di pelajaran sastra dan bahasa, siswa dapat menganalisis novel dan cerita pendek dan menentukan mengapa konflik terjadi, bagaimana konflik mengalami eskalasi, 
dan bagaimana konflik diselesaikan. Ketika mengarang, siswa dapat menulis tentang pengalaman berunding dengan anggota keluarganya, atau pengalaman membantu orang tua dan tetangga.

Prinsip resolusi konflik bahkan bisa diintegrasikan kepada mata pelajaran yang sepintas tampak tidak berkaitan dengan perdamaian dan resolusi konflik. Misalnya, dalam mata pelajaran matematika, siswa dapat bekerja sama menyusun rencana pembuatan taman kota yang menampung semua kepentingan masyarakat, lengkap dengan anggaran yang diperlukan supaya taman tersebut dapat dibangun. Dalam mata pelajaran musik, prinsip-prinsip harmoni dan disharmoni dapat didiskusikan kemiripannya dengan proses pemecahan masalah. Begitu pula, di pelajaran olah raga, siswa dapat diajak mendiskusikan beda permainan yang bersifat kompetitif dari permainan yang kolaboratif, yang dapat menghambat atau menopang sportivitas dalam berolahraga.

Kelas yang damai bertujuan membangun kapasitas siswa dalam menyelesaikan konflik dengan mengetahui sebab-sebab konflik - keterampilan menganalisis konflik, mengidentifikasi faktor penyebab dan eskalasi konflik. Selain itu, siswa juga mempelajari aspek kognitif dan afektif yang menyertai konflik - memahami persepsi, mispersepsi, dan bias dalam konflik, mengidentifikasi perasaan-perasaan yang timbul karena konflik, mengelola amarah dan perasaan lain. Akhirnya, siswa juga dibekali cara menangani dan menyikapi konflik secara konstruktif - mendengar secara aktif, berkomunikasi secara efektif, mengidentifikasi kepentingan bersama, dan mengeksplorasi pilihan-pilihan jalan keluar yang dapat memenuhi kepentingan bersama. Jika tujuan di atas dapat tercapai, maka anggota komunitas sekolah dapat mewujudkan sekolah yang damai (Crawford dan Bodine 1996, 33-34).

\section{Sekolah yang damai}

Pendekatan ini berbeda dari banyak sekolah yang memandang semua konflik adalah negatif dan destruktif - yang disebut 
David W. Johnson dan Roger T. Johnson "sekolah konflik negatif". Konflik di lingkungan sekolah, baik yang melibatkan siswa, guru, dan staf, dipandang sebagai sumber masalah yang menimbulkan rasa takut, kecemasan, ketidakamanan, dan sikap membela diri. Selaras dengan pandangan ini, sekolah berusaha menutup-nutupi, menghindari, dan mengingkari keberadaan konflik. Selain itu, sekolah tidak menyiapkan siswa, guru dan staf supaya dapat mengelola konflik karena hal itu dianggap akan mendorong timbulnya lebih banyak konflik lagi. Tentu saja, anggapan ini bisa terbukti - karena tidak dibekali pengetahuan dan keterampilan resolusi konflik, siswa dan guru menangani konflik dengan cara mereka sendiri (Johnson dan Johnson 1995, 14-15).

Seperti tampak dari namanya, pendekatan sekolah yang damai (peaceable school) menjadikan seluruh sekolah sebagai fokus pendidikan perdamaian dan resolusi konflik (Crawford dan Bodine 1996, 39). Sekolah yang damai menjadikan resolusi konflik sebagai sistem operasi membina sekolah dan juga kelas. Prinsip dan proses resolusi konflik dipelajari dan digunakan setiap anggota komunitas sekolah, termasuk pegawai perpustakaan, konselor, kepala sekolah, guru, orang tua, siswa, staf administrasi, petugas kebersihan, dan satuan pengaman. Setiap anggota komunitas sekolah belajar menggunakan konsep dan keterampilan resolusi konflik. Sekolah yang damai mencerminkan kepedulian, kejujuran, kerjasama, dan apresiasi terhadap perbedaan.

Sekolah yang damai mengintegrasikan pendidikan resolusi konflik ke dalam operasional sekolah. Ini mencakup usaha-usaha menciptakan lingkungan belajar bersama, praktik keterampilan resolusi konflik secara langsung, sistem sekolah yang nirpaksa dan nirintimidasi, integrasi konsep dan keterampilan resolusi konflik ke dalam kurikulum sekolah, termasuk budaya sekolah. Semua anggota komunitas sekolah menerapkan keterampilan manajemen konflik untuk mengatasi masalah interpersonal dan intergrup dan masalah-masalah yang dihadapi, siswa, guru, administrasi, dan orang tua. Selain itu, sekolah menyediakan pelatihan di bidang pemecahan masalah, negosiasi dan mediasi. 
Institusionalisasi Manajemen Konflik Berbasis Sekolah

$\overline{\text { Dengan demikian, sekolah yang damai menggabungkan pendeka- }}$ tan kurikulum proses, mediasi, dan kelas yang damai.

\section{Perundungan}

Perundungan adalah salah satu masalah yang sering ditemui di sekolah, sehingga banyak guru, orang tua, dan siswa sendiri yang menganggap ini sebagai "hal biasa". Ini adalah anggapan yang salah dan berbahaya. Perundungan menyebabkan siswa kurang konsentrasi, bolos, atau putus sekolah sehingga mengganggu dan menurunkan prestasi akademik pelaku perundungan dan korbannya. Perundungan juga menimbulkan dampak psikologis yang negatif seperti depresi dan rendah diri. Selain itu, perundungan yang tidak ditangani dengan tepat akan melanggengkan kekerasan tersebut. Praktik perundungan mengubah sekolah menjadi tempat berbahaya bagi perkembangan kognisi dan emosi siswa. Perlu dicatat, dampak negatif perundungan cenderung bersifat menahun.

Pengamat perundungan Daniel Olweus, mendefinisikan perundungan sebagai tindakan negatif yang dilakukan siswa atau beberapa siswa terhadap siswa atau beberapa siswa lain secara berulang dan dalam waktu relatif lama. A student is being bullied or victimized when he or she is exposed, repeatedly and over time, to negative actions on the part of one or more other students (Olweus 1993, 9). Tindakan negatif tersebut bersifat agresif dan secara sengaja bertujuan melukai atau menyakiti. Selain itu, tindakan tersebut dilakukan berulang-ulang. Tindakan tersebut juga terjadi dalam hubungan antarsiswa yang ditandai ketimpangan kekuatan. Akhirnya, biasanya tindakan tersebut terjadi tanpa ada provokasi dari korban.

Pihak-pihak yang terlibat dalam tindakan perundungan adalah pelaku, korban, dan penonton. Pelaku adalah aktor utama. Biasanya, aktor utama ditemani sejumlah anak sebagai aktor pendukung. Para pelaku ini yang mengambil inisiatif perundungan, lebih kuat dan agresif dari korban, dan cenderung berasal dari keluarga yang menggunakan kekerasan dan hukuman fisik 
terhadap anak. Korban biasanya lebih muda dan lebih lemah dari pelaku. Korban cenderung berasal dari keluarga yang mengalami masalah dalam komunikasi dan hubungan antaranggota keluarga, termasuk orang tua yang terlalu protektif terhadap anak. Akhirnya, penonton ialah mereka yang menyaksikan kejadian perundungan tapi tidak melakukan apa-apa untuk menghentikannya karena satu dan lain hal.

Perundungan, dengan demikian, menimbulkan dampak negatif terhadap siswa dan mengganggu kedamaian di sekolah. MKBS menangani masalah perundungan dengan berbagai cara. Contohnya adalah memfasilitasi korban dan penonton supaya melaporkan insiden perundungan. Pendekatan kelas yang damai menjadikan kelas sebagai tempat belajar yang aman. Pendekatan sekolah yang damai menjadikan sekolah sebagai tempat yang aman bagi semua. Suasana aman ini bersumber dari lingkungan fisik dan lingkungan non-fisik sekolah. Akhirnya, sekolah dapat bekerjasama dengan keluarga dan masyarakat mengatasi komunikasi agresif di dalam keluarga dan layanan konsultasi bagi korban perundungan (Olweus 1993; Panggabean dkk. 2015).

\section{Keluarga dan Masyarakat}

Masalah atau kekerasan yang terjadi di keluarga dan masyarakat akan memengaruhi kekerasan di sekolah. Sebagai contoh, merosotnya struktur keluarga di masyarakat adalah salah satu faktor penyebab kekerasan di sekolah. Kekerasan dan penyalahgunaan narkoba di dalam keluarga adalah faktor lain penyebab kekerasan di sekolah. Selain itu, siswa yang melakukan tindakan kekerasan di masyarakat kemungkinan besar akan melakukan tindakan yang sama di sekolah, dan sebaliknya. Oleh sebab itu, keluarga dan masyarakat sudah seharusnya menjadi bagian dari pendekatan dan program MKBS. Kemitraan, yang melibatkan sekolah, keluarga, aktor negara seperti aparag penegak hukum, dan aktor non-negara termasuk dunia bisnis, adalah kunci keberhasilan MKBS (Austin 2003, 20-21).

Begitu pula, efek pendidikan resolusi konflik di sekolah 
akan terbatas kalau kondisi di masyarakat tidak kondusif. Sekolah menerapkan kebijakan menolak kekerasan - misalnya lewat program menolak kekerasan (zero tolerance for violence). Tetapi, program ini tidak akan efektif jika orangtua menggunakan caracara kekerasan terhadap anak-anak di rumah. Semangat toleransi yang dikembangkan di sekolah dapat luntur jika perkampungan tempat anak tinggal sering diwarnai keributan dan perkelahian antarwarga. Perilaku nirkekerasan yang ditanamkan di kelas sulit diinternalisasi murid karena maraknya aneka tayangan televisi, permainan komputer, dan buku bacaan yang sarat kekerasan di lingkungan mereka.

Karenanya, peran serta keluarga dan masyarakat adalah kunci keberhasilan MKBS di sekolah. Selain itu, keberhasilan program resolusi konflik di sekolah tak bisa dilepaskan dari dukungan dan peran serta keluarga dan masyarakat. Program resolusi konflik apa pun yang diterapkan sekolah tidak akan berhasil dengan baik jika tidak didukung lingkungan sosial sekolah. Pada titik ini, sekolah perlu berkoordinasi dengan masyarakat, baik secara langsung, melalui komite sekolah, atau melalui orangtua murid. Sekolah dapat menyelenggarakan diskusi, konsultasi, dan pelatihan yang diikuti anggota masyarakat dan orangtua murid. Sekolah juga dapat membiasakan komunikasi dengan orangtua melalui, misalnya, buku penghubung.

Peran masyarakat dalam MKBS tidak hanya dengan menciptakan lingkungan damai dan nirkekerasan. Lebih jauh, masyarakat dapat berperan sebagai nara sumber dalam aneka kegiatan di sekolah. Kepolisian, misalnya, dapat menanamkan semangat berlalu lintas yang tidak agresif serta kepatuhan terhadap undang-undang yang berlaku. Petugas kesehatan di Puskesmas setempat dapat mengajarkan pentingnya sanitasi, ketersediaan pelayanan kesehatan yang nirdiskriminasi, pengobatan murah, dan sebagainya. Tokoh agama dan pengurus rumah ibadah dapat menyampaikan gagasan perdamaian dari sudut pandang agama-agama yang berbeda, serta dapat memfasilitasi murid dan siswa supaya berkunjung ke rumah ibadah agama lain. Dengan demikian, MKBS bisa menjadi bagian dari pembelajaran 
berbasis masyarakat.

Sekolah dapat merancang kurikulum MKBS yang sesuai bagi sekolah dan masyarakat tempat sekolah berada. Konteks masyarakat, misalnya di pedesaan atau di perkotaan, akan memengaruhi kurikulum yang dikembangkan sekolah di masyarakat tersebut. Begitu pula, variasi masalah atau isu konflik yang paling sering dihadapi sekolah, mulai dari tawuran, perundungan, sampai penyalahgunaan narkoba, akan menjadi pertimbangan ketika merancang kurikulum resolusi konflik. Karenanya, pemetaan dan penaksiran konflik (assessment) di suatu sekolah perlu dilakukan sebelum menentukan racikan kurikulum resolusi konflik yang akan dilembagakan (Panggabean dkk. 2015).

\section{Institusionalisasi}

Interaksi sosial di sekolah, baik di dalam kelas, di pekarangan sekolah, di lapangan olah raga, dan di kantor melibatkan banyak pihak yang memiliki kepentingan yang berbeda dan kadang-kadang tidak selaras. Ketika di kelas, siswa yang terlambat atau tidak melaksanakan pekerjaan rumah menimbulkan konflik dengan guru yang seringkali mencakup unsur emosi (rasa marah) dan perilaku konflik seperti memukul. Ketika di lapangan olah raga, siswa atau kelompok siswa yang berasal dari kelas berbeda memperebutkan fasilitas olahraga pada saat yang bersamaan.

Di kantin sekolah, kesalahpahaman antara dua siswa atau lebih segera mengalami eskalasi sehingga menimbulkan perkelahian. Di halaman sekolah, beberapa siswa yang tadinya bercanda, bertengkar, dan saling memaki akhirnya melanjutkan persoalan tersebut setelah sekolah usai, dengan berkelahi. Siswa yang berasal dari dua sekolah berbeda saling mencaci dan kemudian tawuran. Tidak jarang, konflik antar-siswa terkait dengan pacaran. Jadi, perilaku konflik dapat timbul dari interaksi sosial di sekolah. Tetapi, banyak sekolah tidak melembagakan patokan dan prinsip yang dapat menjadi parameter bagi perilaku siswa, guru, dan pihak-pihak lain di lingkungan sekolah. Pelem- 
bagaan MKBS menjadikannya sebagai pedoman dan parameter bagi perilaku dan kegiatan siswa, guru, dan pihak-pihak lain di lingkungan sekolah.

Akan tetapi, bagaimana melembagakan ide, prinsip, dan keterampilan MKBS dalam kehidupan sekolah? Ini adalah bagian dari persoalan yang lebih umum, yaitu bagaimana melembagakan ide, prinsip, dan keterampilan ke dalam kehidupan sosial. Ilmu resolusi konflik, misalnya seperti karya klasik Thomas C. Schelling (1960), The Strategy of Conlict, telah membicarakan masalah ini. Tantangan ini juga pernah dibicarakan ilmuwan politik seperti Judith Goldstein dan Robert Keohane (1993). Gagasan dan praktik MKBS secara perlahan dan bertahap dapat dilembagakan ke dalam kultur sekolah. Pelembagaan ini akan menjadikan MKBS sebagai bagian yang tak terpisahkan dari proses belajar mengajar secara keseluruhan, yang melibatkan siswa, guru, serta staf, dan pengurus sekolah.

\section{Makna Pelembagaan dan Tiga Mekanisme Pelembagaan}

Apakah yang dimaksud dengan institusi atau lembaga? Jack Knight menyebutkan dua hal penting yang menyangkut pengertian institusi. Pertama, institusi adalah "seperangkat ketentuan yang mengatur interaksi sosial dengan cara-cara tertentu" (Knight 1992, 2). Dalam konteks MKBS, seperangkat ketentuan yang mengatur interaksi berbagai pihak di lingkungan sekolah merujuk kepada enam unsur MKBS yang disebutkan di atas. Kedua, supaya seperangkat ketentuan itu dapat disebut lembaga, ketentuan-ketentuan tersebut harus terlebih dahulu diketahui dan dianut orang-orang yang terlibat dalam interaksi sosial dimaksud (Knight 1992, 2-3). MKBS dapat disebut melembaga jika siswa, guru, dan staf di sekolah secara bersama-sama sudah menganut berbagai pendekatan dan ketentuan MKBS.

Selaras dengan pengertian institusi di atas, maka institusionalisasi atau pelembagaan adalah proses mengintegrasikan ketentuan, prinsip, dan praktik MKBS ke dalam interaksi yang melibatkan berbagai pihak di sekolah. Melalui proses institusion- 
alisasi, MKBS mendapatkan legitimasi dan stabilitas, menjadi bagian dari pola interaksi berbagai pihak di sekolah. Jika ada masalah dan konflik di sekolah, semua pihak yakin bahwa masalah dan konflik tersebut akan diselesaikan sesuai dengan ketentuan MKBS yang berlaku. Selain itu, implementasi MKBS tak lagi tergantung kepada kehendak orang-perorang - termasuk, misalnya, kepala sekolah. Semua pihak mematuhi dan menghargai MKBS.

Ada tiga jalan atau mekanisme yang berbeda, tetapi perlu ditempuh bersama-sama, menuju pelembagaan MKBS. Yang pertama adalah jalur perseorangan atau individu. Dalam hal ini, MKBS menjadi pedoman atau roadmap pribadi, baik siswa, guru, dan staf di sekolah. Yang kedua adalah jalur kelompok. Dalam hal ini, MKBS menjadi fokus dan rujukan kelompok - yang disebut Schelling dengan istilah "focal point". Akhirnya, yang ketiga, adalah jalur pelembagaan melalui penetapan MKBS sebagai aturan organisasi (Goldstein and Keohane 1993, 12-13). Dalam konteks sekolah, ini berarti mengintegrasikan MKBS ke dalam statuta sekolah. Melalui ketiga mekanisme ini, pengetahuan, norma, prinsip, dan praktik MKBS akan melembaga di dalam budaya sekolah.

\section{Mekanisme individu atau perseorangan}

Menyemai pengetahuan dan keterampilan manajemen konflik kepada perseorangan yang berada di lingkungan sekolah adalah salah satu mekanisme pelembagaan MKBS. Melalui berbagai metode dan pendekatan belajar resolusi konflik, siswa, guru, dan staf memiliki pengetahuan dan keterampilan yang memungkinkan mereka menangani konflik di sekolah dengan mengikuti ketentuan MKBS. Apabila siswa, guru, staf, dan karyawan sekolah menangani konflik yang mereka hadapi dengan cara-cara damai dan nirkekerasan, maka MKBS telah melembaga: Menjadi preferensi (pilihan tindakan) dan panduan invididu setiap kali dihadapkan kepada konflik dan kekerasan. Selaras dengan ini, MKBS menjadi kebiasaan individu, yang dapat diikuti teman-teman individu tersebut. 
Oleh sebab itu, prinsip, norma, dan keterampilan manajemen konflik nirkekerasan perlu diberikan kepada perseorangan atau individu. Ini mencakup guru, siswa, staf, dan karyawan sekolah termasuk satuan pengaman (satpam) dan petugas kebun sekolah. Secara perlahan dan bertahap mereka mempelajari gagasan dan keterampilan memecahkan masalah, musyawarah, negosiasi, mediasi, dan lain-lain sehingga pengetahuan dan keterampilan pokok manajemen konflik dapat mereka kuasai. Penguasaan atas pokok-pokok manajemen konflik akan membantu siswa, guru, dan staf sekolah menerapkan dan mempraktikkan manajemen konflik berbasis sekolah. Sebagai contoh, jika dihadapkan kepada masalah, invididu tidak menyelesaikannya dengan caracara konfrontatif dan dengan menggunakan kekerasan, karena mereka memiliki pengetahuan dan keterampilan manajemen konflik nirkekerasan.

Dengan kata lain, pengetahuan dan praktik manajemen konflik secara damai menjadi "peta jalan" bagi invididu atau perseorangan yang menguasai dan mengamalkannya. Peta jalan itulah yang digunakan individu apabila dihadapkan kepada masalah dan konflik. Individu tersebut akan tetap di jalan itu dan meninggalkan cara-cara lain yang keras dan destruktif. Sebagai hasilnya, MKBS menjadi peta jalan dalam interaksi individu tersebut di masa yang akan datang. Karena penggunaan MKBS mendatangkan manfaat yang positif, pengalaman pribadi ini akan menjadi rujukan normatif bagi invidu tersebut. Bahkan, prosesnya tidak berhenti di sini. Pada gilirannya, peta jalan invididual itu akan menjadi tekanan kepada jaringan atau kelompok bermain individu tersebut.

Supaya mekanisme pertama ini dapat diterapkan dengan baik, sebaiknya sekolah terlebih dahulu melakukan perkiraan dan pemetaan. Fokusnya adalah pada bentuk dan jenis konflik yang paling sering terjadi di lingkungan sekolah, dan cara-cara yang digunakan siswa menangani konflik tersebut, termasuk cara kekerasan dan nirkekerasan. Ini akan menjadi bahan yang berguna bagi beberapa tujuan. Salah satu di antaranya adalah bahan mengidentifikasi pengetahuan dan keterampilan yang 
paling diperlukan siswa khususnya. Kegunaan lain adalah sebagai bahan menentukan metode dan pendekatan menyemai pengetahuan dan keterampilan resolusi konflik bagi siswa (Panggabean dkk. 2015).

\section{Mekanisme kelompok dan interaksi siswa}

Selain sebagai peta jalan, pengetahuan dan keterampilan manajemen konflik dapat dijadikan sebagai fokus koordinasi dan perekat dalam kegiatan berbagai kelompok interaksi siswa. Termasuk di antaranya adalah kelompok minat, olah raga, kesenian, pencinta alam, kerohanian, dan pengelompokan siswa lainnya. Interaksi antara kelompok siswa senior dan junior adalah contoh lain. Seperti diketahui, konflik di lingkungan sekolah seringkali terjadi dalam konteks kelompok kegiatan, minat, dan interaksi seperti ini. Akan tetapi, siswa sering sekali menangani konflik dan masalah yang mereka hadapi dengan cara-cara yang tidak bersahabat. Bahkan, kekerasan sering timbul dalam kehidupan kelompok-kelompok siswa. Akibatnya, proses belajar mengajar terganggu dan semua pihak merugi.

Karenanya, pelembagaan MKBS ke dalam mekanisme kelompok aktivitas dan interaksi siswa merupakan strategi yang tepat. Dalam hal ini, prinsip, pengetahuan, dan keterampilan MKBS menjadi rujukan bersama dalam interaksi sosial di dalam kelompok dan unit kegiatan siswa tersebut. Apabila sekolah menetapkan bahwa cara-cara damai dan nirkekerasan harus menjadi pedoman dalam menyelesaikan konflik dan masalah yang timbul dalam unit-unit kegiatan siswa di sekolah, maka MKBS akan melembaga di bidang-bidang kegiatan yang menarik perhatian siswa. MKBS akan mengatur interaksi antarkelompok dan unit kegiatan siswa sehingga dapat berjalan dengan lancar. Dengan kata lain, MKBS menjadi "focal point" yaitu titik koordinasi, solusi prominen, atau pedoman interaksi kelompok ketika dihadapkan masalah dan konflik yang timbul.

MKBS menjadi perekat yang menyatukan dan merawat kebersamaan di antara berbagai kelompok siswa yang tersebar di 
berbagai unit kegiatan dan kepanitiaan di sekolah. Jika konflik timbul, siswa dapat menanganinya tanpa menggunakan agresi, kekerasan, atau permusuhan. Karenanya, kepentingan siswa yang memiliki minat dan perhatian berbeda-beda terjaga. Tidak ada kelompok siswa yang merasa diuntungkan jika mereka menggunakan kekerasan. Malahan, nama baik mereka bisa terganggu karena menggunakan cara kekerasan dan agresi. Sebagai implikasinya, kegiatan kelompok-kelompok siswa menjadi tergantung pada implementasi MKBS. Guru, kepala sekolah, dan staf dapat memusatkan perhatian pada proses mengajar dan belajar sebagai inti kegiatan sekolah.

Serupa mekanisme pertama, pelembagaan mekanisme kedua memerlukan pemetaan dan penaksiran konflik. Konflik yang terjadi di berbagai unit kegiatan ekstrakulikuler dipetakan dan diteliti kecenderungannya. Ini mencakup kesenian, olah raga, kerohanian, kepanitiaan, dan lain-lain. Yang juga perlu diperiksa adalah seberapa besar ketergantungan dan kecenderungan siswa menyelesaikan konflik dengan cara-cara yang agresif dan menggunakan kekerasan. Ini semua akan menjadi masukan penting ketika sekolah mengidentifikasi pengetahuan dan keterampilan apa yang paling diperlukan supaya keanekaragaman kegiatan siswa di sekolah dapat dirawat. Pada saat yang sama, kelompok kegiatan siswa menjadi arena mengapresiasi MKBS (Panggabean dkk. 2015).

\section{Pelembagaan melalui statuta sekolah}

Akhirnya, mekanisme ketiga, adalah pelembagaan melalui statuta sekolah. Sekolah pada umumnya tidak memiliki rujukan bersama penanganan konflik di sekolah. Jika konflik antarsiswa terjadi, cara penanganannya seringkali konfrontatif. Yang kuat menang, yang lemah kalah tetapi memelihara dendam dan rasa benci yang di kemudian hari bisa menimbulkan kekerasan baru. Guru merasa konflik di sekolah bukanlah urusan mereka. Begitu pula, kepemimpinan kepala sekolah seringkali tidak mencakup kepemimpinan mendidik siswa supaya memilih cara-cara yang 
bersahabat dan nirkekerasan ketika mereka mengelola konflik. Ketika kekerasan yang serius terjadi, misalnya tawuran intrasekolah atau antar-sekolah, sekolah meminta bantuan polisi. Proses belajar mengajar terganggu, dan nama baik sekolah rusak.

Sekolah dapat mengatasi masalah-masalah di atas dengan melembagakan MKBS ke dalam statuta sekolah. Pokok-pokok peraturan dan norma sekolah biasanya tercantum dalam statuta sekolah. Statuta sekolah dapat dipandang sebagai anggaran dasar dan anggaran rumah tangga sekolah, dokumen yang menghimpun pokok-pokok aturan, prinsip, dan norma sekolah. Statuta adalah konstitusi sekolah. Pelembagaan MKBS ke dalam statuta sekolah berarti pencantuman prinsip dan metode MKBS ke dalam statuta sekolah tersebut. Pelembagaan ke dalam statuta ini akan melengkapi dua mekanisme yang disebutkan di atas, yaitu MKBS sebagai pedoman pribadi dan fokus kelompok.

Ada beberapa ketentuan MKBS yang dimasukkan ke dalam statuta sekolah. Salah satu di antaranya adalah definisi dan tujuan MKBS. Ketentuan lainnya adalah bentuk kegiatan yang dicakup MKBS, seperti kurikulum proses, kelas yang damai, sekolah yang damai, anti-perundungan, dan lain-lain. Statuta sekolah dapat juga memuat ketentuan mengenai perencanaan, pelaksanaan, dan evaluasi program dan kegiatan MKBS di sekolah. Selain itu, statuta sekolah harus menyebutkan siapa yang memegang kendali koordinasi kegiatan dan program MKBS di sekolah. Kepala sekolah dibantu konselor, misalnya, dapat ditetapkan sebagai koordinator dimaksud (Panggabean dkk. 2015). Koordinator ini bertugas memastikan komponen MKBS dalam statuta benar-benar ditegakkan.

Jika prinsip, norma, dan praktik MKBS telah tertanam dalam statuta sekolah, berarti sekolah tersebut telah membuat komitmen serius dalam menerapkan MKBS. MKBS menjadi rujukan bagi penanganan masalah dan konflik di lingkungan sekolah. MKBS mengesampingkan cara dan strategi lain menangani konflik. Begitu pula, MKBS menjadi kendala atau rintangan terhadap penggunaan cara-cara penyelesaian konflik dan penan- 
ganan masalah yang konfrontatif dan keras seperti perkelahian, intimidasi, perundungan, dan lain-lain. Selaras dengan ini, semua pihak di lingkungan sekolah, mulai dari guru, siswa, sampai kepada karyawan akan mengikuti aturan MKBS yang ada dalam statuta sekolah. Inilah yang disebut dengan pelembagaan MKBS ke dalam statuta sekolah.

Sekolah terlebih dahulu melakukan perkiraan atau assessment terhadap bentuk, jenis, dan frekuensi insiden konflik di sekolah. Cara-cara yang paling sering digunakan dalam menangani konflik di sekolah juga perlu dipetakan. Selain itu, perlu diperhatikan aspek-aspek pelembagaan dan tantangannya. Kemudian, sekolah memutuskan apa yang akan dimasukkan ke dalam statuta sekolah dan apa yang dapat dituangkan ke dalam panduan dan kebijakan yang lebih khusus. Statuta bisa mencakup prinsip dan ketentuan umum mengenai MKBS, dan rinciannya dicantumkan ke dalam kebijakan kepala sekolah, misalnya.

Perlu dicatat, sekolah-sekolah yang melembagakan MKBS memulainya dengan cara yang berbeda. Salah satu sekolah melembagakan MKBS melalui cetak biru atau blueprint sekolah, dengan mencantumkan MKBS dalam statuta yang menjadi konstitusi sekolah. Dalam implementasinya, sekolah melakukan pelatihan kepada siswa, guru, dan staf termasuk satuan pengaman, petugas kebersihan, dan pegawai kantin sekolah. Ini menjadi strategi memperkuat apa yang sudah tercantum dalam statuta sekolah. Pelatihan tersebut dilakukan secara rutin. Kemudian, berdasarkan praktik dan implementasi MKBS, statuta secara periodik diperbaiki seiring dengan perkembangan sekolah (Panggabean dkk 2015).

Sekolah yang lain melembagakan MKBS karena sekolah dihadapkan kepada berbagai bentuk kekerasan yang memerlukan penanganan segera. Dalam hal ini, tahapan-tahapan yang dilakukan mencakup pembuatan kebijakan penerapan MKBS. Sekolah melakukannya dengan melibatkan orang tua, wali, guru, staf, dan siswa. Tujuannya adalah supaya ada pemahaman yang sama, dan supaya kepentingan bersama terbentuk. Dengan kata lain, supaya 
semua yang berkepentingan mendukung pelembagaan MKBS. Selain itu, sekolah mengadakan pelatihan mediasi sejawat dan keterampilan resolusi konflik yang lain. Dukungan dan legitimasi MKBS diperkuat dengan sosialisasi keterampilan resolusi konflik dan mediasi sejawat (Adami and Norton 1996, 19-23).

\section{Penutup}

Pengetahuan dan praktik resolusi konflik yang diterapkan di sekolah telah mengalami kemajuan pesat, mencakup berbagai unsur, khususnya kurikulum proses, kelas yang damai, sekolah yang damai, mediasi sejawat, anti-perundungan, dan peran serta keluarga dan masyarakat. Berbagai unsur kurikulum pendidikan resolusi konflik yang disebut MKBS ini dapat dilembagakan di sekolah-sekolah di Indonesia. Selain menyangkut usaha menciptakan lingkungan belajar yang damai bagi semua pihak di sekolah, pengetahuan dan keterampilan resolusi konflik menopang proses belajar-mengajar dalam arti yang luas, seperti bekerja sama dalam belajar dan mengelola kelas dengan caracara nirpaksa.

MKBS dapat dilembagakan di dalam sekolah dengan menggunakan tiga jalur pelembagaan, yaitu melalui individu, kelompok, dan statuta sekolah. Walaupun masih terbatas, pengalaman aktual sekolah-sekolah yang menerapkan MKBS sudah dapat dikaji dan dievaluasi. Sudah ada contoh dan model yang dapat digunakan sekolah lain yang ingin menerapkan dan melembagakan MKBS. Pelembagaan ini akan menghasilkan implementasi MKBS yang teratur, stabil, dan diterima seluruh pemangku kepentingan di sekolah. Sekolah pun kembali menjadi lingkungan yang aman dan menyenangkan bagi semua. Dan sekolah dapat memusatkan perhatian, waktu dan enersi kepada tugas pokoknya: belajar dan mengajar. 


\section{BIBLIOGRAFI}

Adami, Randolph dan Margaret Norton, "Not in my school you don't! Preventing violence in the middle-level school" NASSP Bulletin, 1996, 80 (April) hal. 19-23.

Austin, Vance L., "Fear and Loathing in the Classroom: A candid look at school violence and the policies and practices that adress it" Journal of Disability Policy Studies, Vol. 4, 2003: 17-22.

Bond, Lyndal, Sara Glover, C. Godfrey, Helen Butler, dan George C. Patton, "Building Capacity for System-Level Change in Schools: Lessons from the Gatehouse Project," Health Education \& Behavior, Vol. 28 (3), 2001, hal. 368-383.

Crawford, Donna dan Richard Bodine. Conflict Resolution Education: A Guide to Implementing Programs in Schools, Youth-Serving Organizations, and Community and Juvenile Justice Settings. US Department of Justice dan US Department of Education, 1996. Goldstein, Judith dan Robert O. Keohane, eds., Ideas and Foreign Policy: Beliefs, Institutions, and Political Change. Ithaca: Cornell University Press, 1993.

Harris, Ian M. "Peace-Building Responses to School Violence" NASSP Bulletin, Vol. 84, 2000, hal. 5-24.

Heydenberk, Roberta Anna, dan Warren R. Heydenberk, "Increasing Meta-Cognitive Competence through Conflict Resolution," Education and Urban Society, Vol. 37 No. 4, 2005, hal. 431-452.

Johnson, David W. dan Roger T. Johnson, "Energizing Learning: The Instructional Power of Conflict" Educational Researcher, Vol. 38, No. 1, hal. 37-51.

Johnson, David W. dan Roger Johnson, "Peer Mediation in an Inner-City Elementary School," Urban Education, Vol. 36, 2001, 165-178.

Johnson, David W. dan Roger T. Johnson, Reducing School Violence through Conflict Resolution, Alexandria: Association for Supervision and Curriculum Development, 1995.

Knight, Jack, Institutions and Social Conflict. New York: Cambridge University Press, 1992. 
Knight, Peter T., "Complexity and Curriculum: A Process Approach to Curriculum-making," Teaching in Higher Education, Vol. 6, No. 3, 2001, hal. 369-381.

Noel, Brett Riley, "Conflict Resolution Education in Indonesia: Mapping Adaptations and Meanings" (Disertasi Universitas Ohio, 2008).

Olweus, Dan, Bullying at Schools. What we know and what we can do. London: Blackwell Publishing, 1993.

Panggabean, Rizal dkk, Manajemen Konflik Berbasis Sekolah. Jakarta: Alvabet, 2015.

Schelling, Thomas C., The Strategy of Conflict. Cambridge, MA: Harvard University Press, 1960.

Slavin, RobertE., "Cooperative Learning and Academic Achievement: Why Does Groupwork Work?" Anales de Psicología, Vol. 30 No. 3, 2014, hal. 785-791.

Slavin, Robert E., "Cooperative Learning," Review of Educational Research Summer, 1980, Vol. 50, No. 2, hal. 315-342. 